Prepared in cooperation with the Sac and Fox Tribe of the Mississippi in lowa

Effect of Groundwater Withdrawals, River Stage, and Precipitation on Water-Table Elevations in the lowa River Alluvial Aquifer near Tama, lowa, 2017-20

Open-File Report 2021-1019 



\section{Effect of Groundwater Withdrawals, River Stage, and Precipitation on Water-Table Elevations in the lowa River Alluvial Aquifer near Tama, lowa, 2017-20}

By Lance R. Gruhn and Adel E. Haj

Prepared in cooperation with the Sac and Fox Tribe of the Mississippi in lowa

Open-File Report 2021-1019 


\section{U.S. Geological Survey, Reston, Virginia: 2021}

For more information on the USGS - the Federal source for science about the Earth, its natural and living resources, natural hazards, and the environment—visit https://www.usgs.gov or call 1-888-ASK-USGS.

For an overview of USGS information products, including maps, imagery, and publications, visit https://store.usgs.gov/.

Any use of trade, firm, or product names is for descriptive purposes only and does not imply endorsement by the U.S. Government.

Although this information product, for the most part, is in the public domain, it also may contain copyrighted materials as noted in the text. Permission to reproduce copyrighted items must be secured from the copyright owner.

Suggested citation:

Gruhn, L.R., and Haj, A.E., 2021, Effect of groundwater withdrawals, river stage, and precipitation on water-table elevations in the lowa River alluvial aquifer near Tama, lowa, 2017-20: U.S. Geological Survey Open-File Report 2021-1019, 11 p., https://doi.org/10.3133/ofr20211019.

Associated data for this publication:

Cigrand, C.V., 2019, Geospatial datasets for the flood-inundation study for the lowa River at the Meskwaki Settlement in lowa, 2019: U.S. Geological Survey data release, https://doi.org/10.5066/P912F03L.

U.S. Geological Survey, 2020, USGS water data for the Nation: U.S. Geological Survey National Water Information System database, https://doi.org/10.5066/F7P55KJN.

ISSN 2331-1258 (online) 


\section{Acknowledgments}

The authors would like to thank the Sac and Fox Tribe of the Mississippi in lowa for funding the operation of and maintenance of the streamgaging station and groundwater wells used for this study. 



\section{Contents}

Acknowledgments ……...................................................................................................................

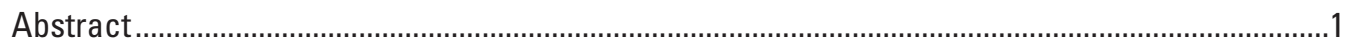

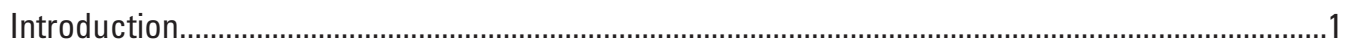

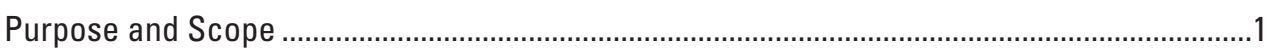

Study Area

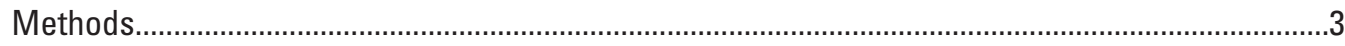

Groundwater Monitoring ..................................................................................................

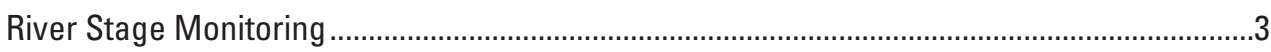

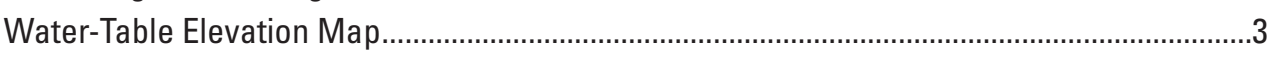

Integrated Qualitative Analysis ................................................................................................

Hydrologic Effect of Groundwater Withdrawals, River Stage, and Precipitation on the lowa River Alluvial Aquifer ...............................................................................................

Effect of Sustained Low Stage on Water-Table Elevations ......................................................

Effect of Sustained High Stage on Water-Table Elevations..........................................................

Variable Stage from Localized Precipitation Events Versus Upstream Flow Events ................9

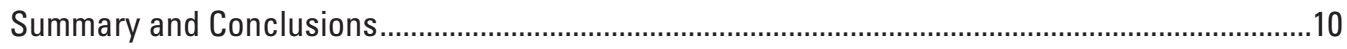

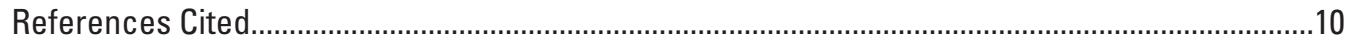

\section{Figures}

1. Map showing geographic area, local infrastructure, landscape features, and data collection sites near Tama, lowa, 2017-20 ............................................................2

2. Map showing water-table elevations typical of drought/low flow conditions for the lowa River alluvial aquifer near Tama, lowa, as represented by September 2017 elevations.

3. Graph showing daily mean water-table elevations, relative groundwater withdrawals, and precipitation, July 1 to September 30, 2020

4. Graph showing daily mean water-table elevations, relative groundwater withdrawals, and precipitation, September 1 to November 20, 2018...............................

5. Graph showing daily mean water-table elevations, relative groundwater withdrawals, and precipitation, February 10 to July 10, 2020. 9

\section{Table}

1. Information on data collection sites near Tama, lowa, 2017-20..................................... 


\section{Conversion Factors}

U.S. customary units to International System of Units

\begin{tabular}{|c|c|c|}
\hline Multiply & By & To obtain \\
\hline \multicolumn{3}{|c|}{ Length } \\
\hline inch (in.) & 2.54 & centimeter $(\mathrm{cm})$ \\
\hline inch (in.) & 25.4 & millimeter (mm) \\
\hline foot (ft) & 0.3048 & meter $(\mathrm{m})$ \\
\hline \multicolumn{3}{|c|}{ Area } \\
\hline acre & 4,047 & square meter $\left(\mathrm{m}^{2}\right)$ \\
\hline \multicolumn{3}{|c|}{ Flow rate } \\
\hline gallon per day (gal/d) & 0.003785 & cubic meter per day $\left(\mathrm{m}^{3} / \mathrm{d}\right)$ \\
\hline
\end{tabular}

\section{Datum}

Vertical coordinate information is referenced to the North American Vertical Datum of 1988 (NAVD 88).

Horizontal coordinate information is referenced to the North American Datum of 1983 (NAD 83).

Elevation, as used in this report, refers to distance above the vertical datum.

\section{Abbreviations}

IRAA lowa River alluvial aquifer

MNDNR Meskwaki Nation Department of Natural Resources

NOAA National Oceanic and Atmospheric Administration

USGS U.S. Geological Survey 


\title{
Effect of Groundwater Withdrawals, River Stage, and Precipitation on Water-Table Elevations in the lowa River Alluvial Aquifer near Tama, lowa, 2017-20
}

\author{
By Lance R. Gruhn and Adel E. Haj
}

\section{Abstract}

The Sac and Fox Tribe of the Mississippi in Iowa is the only federally recognized Tribe in the State of Iowa and is commonly known as the Meskwaki Nation. The Tribe owns more than 8,100 acres, referred to as the "Meskwaki Settlement." The Meskwaki Settlement uses a well field that withdraws water from the Iowa River alluvial aquifer (IRAA) to supply drinking water to members of the Tribe. Increased severity and timing of flooding and drought conditions, coupled with water-quality concerns in the Iowa River, have prompted the Meskwaki Nation to start identifying tools to provide a better understanding of how extreme climate events (changes in streamflow, flood frequency, and magnitude and persistence of drought conditions), increasing water-supply demands, and groundwater storage depletion will affect water availability in the IRAA.

From June 2017 through September 2020, the U.S. Geological Survey, in cooperation with the Meskwaki Nation, collected continuous and discrete groundwater level data from 11 wells in a U.S. Geological Survey monitoringwell network. Groundwater level data collected at these wells were assessed with daily precipitation data and compared to changes in stream level elevations and daily groundwater withdrawals to determine how these changes affect groundwater-table elevations. Results from this study could be used to guide the development of a conceptual model for groundwater flow and a groundwater flow model for the IRAA to quantify and forecast the effect of groundwater withdrawals, Iowa River streamflow, and local precipitation on the water table in the IRAA.

\section{Introduction}

The Sac and Fox Tribe of the Mississippi in Iowa is the only federally recognized Tribe in the State of Iowa and is commonly known as the Meskwaki Nation. The Tribe owns more than 8,100 acres, referred to as the "Meskwaki Settlement." The Meskwaki Settlement well field (hereafter referred to as the "well field") source water primarily comes from the Iowa River alluvial aquifer (IRAA) in Tama County, Iowa (fig. 1). Increased severity and timing of floods and droughts in the region, coupled with declining water quality in the Iowa River and potential point source contamination in the floodplain, have raised concern with the Meskwaki Nation that the quantity and quality of the water in the alluvial aquifer may be at risk. The Meskwaki Nation recognized a need for tools to provide a better understanding of how changes in streamflow, flood frequency, and magnitude; persistence of drought conditions; increasing water-supply demands; and groundwater storage depletion will affect water availability in the IRAA.

From June 2017 through September 2020, the U.S. Geological Survey (USGS), in cooperation with The Meskwaki Nation, collected continuous and discrete groundwater level data from 11 wells in a USGS monitoring-well network. Groundwater level data collected in these wells were assessed with daily precipitation data, stream level elevations on the Iowa River (hereafter referred to as "stage"), and daily groundwater withdrawals to determine how variability in these properties affects groundwater-table elevations in the unconfined IRAA near the well field (hereafter referred to as "water table"). Results from this study can be used as the first step in developing a conceptual model for groundwater flow and a groundwater flow model for the IRAA. The groundwater model could be used to quantify and forecast the effects of local precipitation, stage on the Iowa River, and groundwater withdrawals on the water table in the IRAA.

\section{Purpose and Scope}

The purpose of this report is to characterize the hydrodynamics of the IRAA around the well field using daily mean groundwater elevation data, daily mean groundwater withdrawal data, precipitation data, and stage data, collected near Tama, Iowa, from June 30, 2017, to September 30, 2020. 


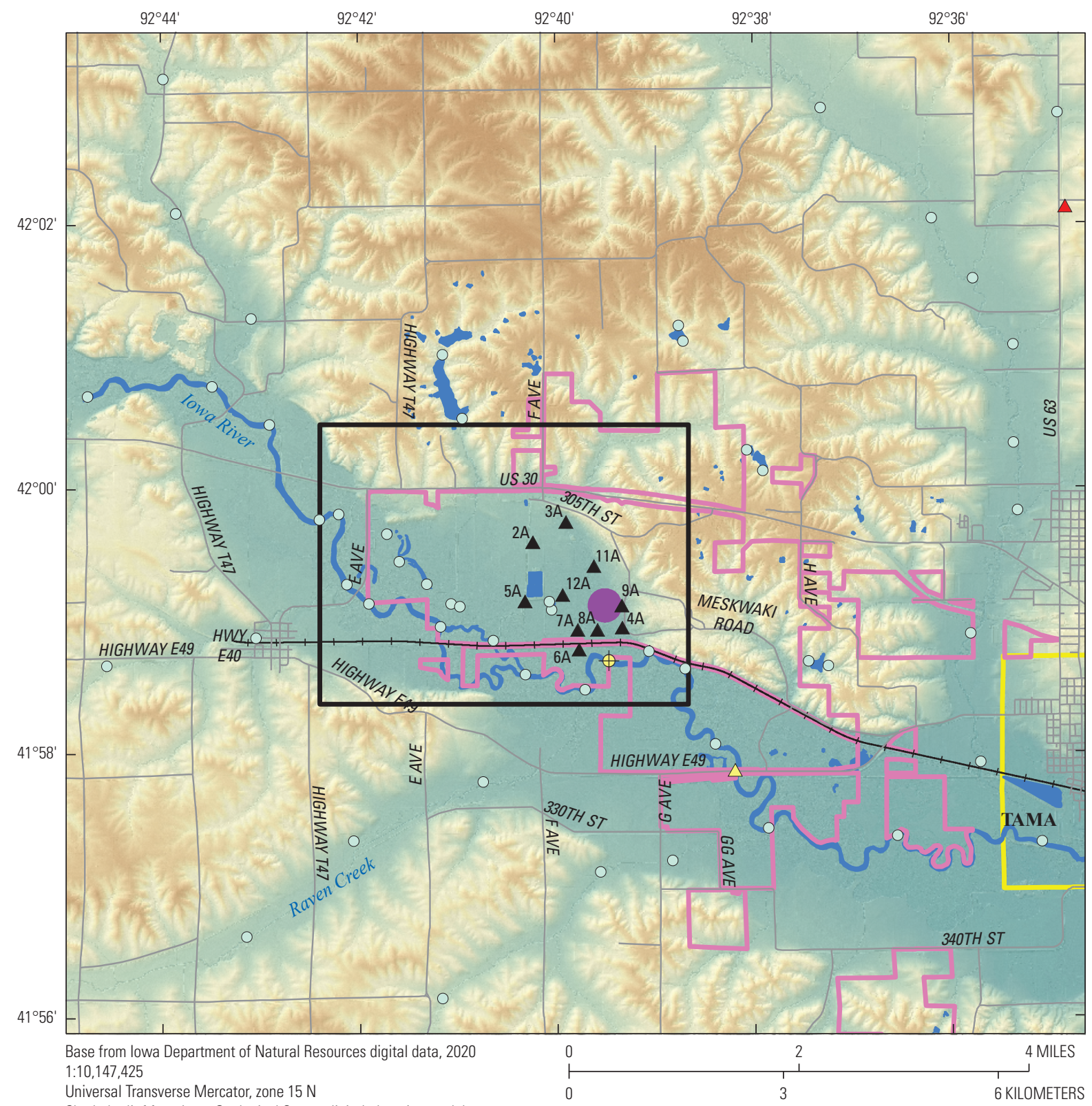

Shaded relief from lowa Geological Survey digital elevation model

North American Datum of 1983

\section{EXPLANATION}

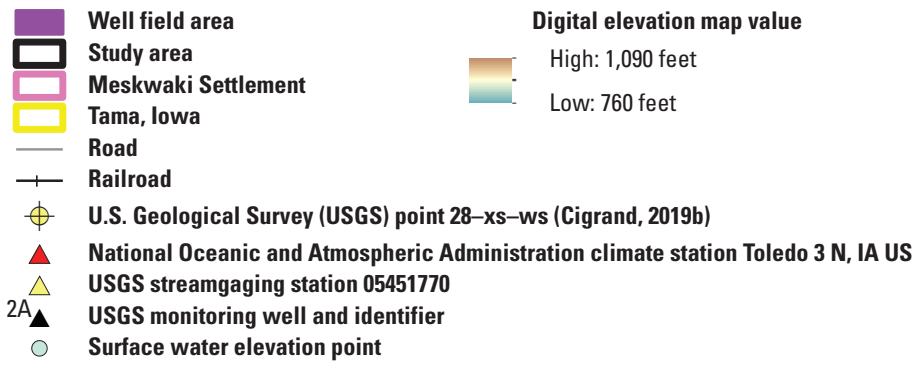

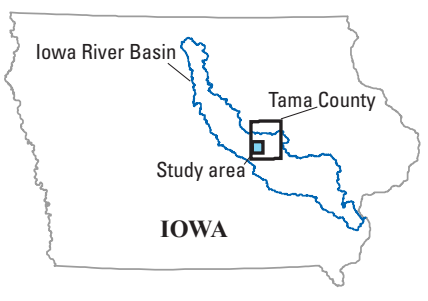

Figure 1. Geographic area, local infrastructure, landscape features, and data collection sites near Tama, lowa, 2017-20. 


\section{Study Area}

The study area is the IRAA around a well field that is west of the city of Tama, Iowa. The IRAA is a surficial, unconfined aquifer generally composed of 40-50 feet (ft) of alluvial sand and gravel deposits in the study area that overlie glacial till (Hallberg and others, 1978; Iowa Geological Survey, 2020). Infrastructure in the study area includes U.S. Highway 30 and the Union Pacific railroad tracks, which are north and south of the well field, respectively. Both are oriented west to east and are elevated within the floodplain to maintain operation during high stages on the Iowa River (fig. 1). The well field is north and east of the Iowa River channel on the alluvial floodplain of the Iowa River; the Iowa River generally trends in a southeasterly direction. Uplands are to the north and east of the well field area and descend steeply to an alluvial floodplain (fig. 1). In the study area, the Iowa River meanders through a broad floodplain with several oxbow lakes and numerous meander scars (Cigrand, 2019a). Onion Creek and Raven Creek are two small tributaries that discharge to the Iowa River within the boundaries of the study area, the most notable being Onion Creek, which flows through and contributes to the drainage through the well field (figs. 1, 2). Climate in the study area is temperate with cold winters and humid, warm summers (Littin and McVay, 2008).

\section{Methods}

To better understand how changes in stage on the Iowa River and adjacent well field operations affect water-table elevations in the IRAA, continuous (one reading every $15 \mathrm{~min}$ utes) groundwater level (wells 2A-12A and 6B) and stage data (Iowa River) were collected by the USGS in the IRAA and on the Iowa River (table 1). These data were analyzed with daily groundwater withdrawal data provided by Meskwaki Nation Department of Natural Resources (MNDNR) staff (Meskwaki Nation Department of Natural Resources, written commun., 2020) and daily precipitation data from a nearby National Oceanic and Atmospheric Administration (NOAA) climate station, "Toledo 3 N, IA US" (National Oceanic and Atmospheric Administration, 2020; fig. 1). Data collected at the 11 groundwater sites and 1 surface water site listed in table 1 can be accessed through the USGS National Water Information System database (U.S. Geological Survey, 2020).

\section{Groundwater Monitoring}

Beginning on June 30 , 2017, continuous groundwater elevation data were collected in six monitoring wells (4A, 7A, $8 \mathrm{~A}, 9 \mathrm{~A}, 11 \mathrm{~A}, 12 \mathrm{~A}$ ) near the well field. In the summer of 2019, the monitoring effort was expanded to include an additional four wells (2A, 3A, 5A, 6A) and in winter of 2020 monitoring began in a newly established well (6B) (table 1). These monitoring wells were established in 2011, except for 6B, which was installed in 2019 to replace a damaged well (6A). These wells were established for the purpose of groundwater level data collection and are screened in the unconsolidated part of the IRAA. Continuous groundwater level data were collected using two types of pressure transducers following methods established by the USGS for collection of groundwater level data (Cunningham and Schalk, 2011). One type had integrated pressure sensors (one in the transducer underwater and one at the top of the cable above the water surface), and data were compensated in real time while logging; the other type required postprocessing for barometric compensation. Continuously logged data were checked using independent manual measurements made to the water surface in the wells. Continuous data were used to compute daily mean groundwater elevation data for analysis in this report.

\section{River Stage Monitoring}

From June 2017 through September 2020, continuous stage data on the Iowa River at County Highway E49 near Tama, Iowa (USGS streamgaging station 05451770), were collected following methods established by USGS for the collection of stage measurements (Rantz and others, 1982) (table 1, fig. 1). These stage data were converted to elevation in feet above the North American Vertical Datum of 1988; then, two Differential Global Positioning System survey points collected on the water surface of the Iowa River by USGS personnel were used to determine an offset (4.16 ft) to the elevation stage data at the location of the streamgaging station (Cigrand, 2019a, b). One survey point used was sampled near the well field (28-xs-ws) and the other (xs15-rb-ws) was sampled about $120 \mathrm{ft}$ downstream from USGS streamgaging station 05451770 (fig. 1). This elevation difference was uniformly applied as an offset to the stage data for USGS site 05451770 to more accurately approximate the elevation of the river closer to the well field. This offset-adjusted dataset was then used for comparison to select periods of groundwater level elevations across the well field.

\section{Water-Table Elevation Map}

A water-table elevation map is a contour map of the water table interpolated from observed water levels, and in this study, surface water body elevations, observed water levels, and several hydrogeologic assumptions were used to interpolate contour line placement. A total of 17 surface water body elevations were extracted from a digital elevation model (Iowa Department of Natural Resources, 2017), and 8 discrete water level measurements from 8 of the 10 wells in the monitoring network were used to help construct the water-table elevation map (fig. 2). Water level measurements collected in September 2017 were used to represent typical low-stage conditions in the Iowa River and were considered representative of a typical drought stress period for the IRAA (fig. 2). Several hydrogeologic assumptions were applied when interpolating 
Table 1. Information on data collection sites near Tama, lowa, 2017-20.

[USGS, U.S. Geological Survey; NAD83, North American Datum of 1983; NAVD 88, North American Vertical Datum of 1988; , degree; ', minute; ", second; IA, Iowa; --, no data or not applicable]

\begin{tabular}{|c|c|c|c|c|c|c|c|}
\hline USGS site number & Station name & $\begin{array}{c}\text { Field } \\
\text { identifier }\end{array}$ & $\begin{array}{l}\text { Latitude } \\
\text { (NAD83) }\end{array}$ & $\begin{array}{c}\text { Longitude } \\
\text { (NAD83) }\end{array}$ & $\begin{array}{c}\text { Year } \\
\text { established }\end{array}$ & $\begin{array}{l}\text { Land surface elevation, } \\
\text { in feet above NAVD } 88\end{array}$ & $\begin{array}{l}\text { Well depth, } \\
\text { in feet }\end{array}$ \\
\hline 415935092401401 & 083N16W23AAAB 2011MMW-2A & $2 \mathrm{~A}$ & $41^{\circ} 59^{\prime} 35^{\prime \prime}$ & $92^{\circ} 40^{\prime} 14^{\prime \prime}$ & 2011 & 837.79 & 39.0 \\
\hline 415944092395401 & 083N16W13CCAD 2011MMW-3A & $3 \mathrm{~A}$ & $41^{\circ} 59^{\prime} 44^{\prime \prime}$ & $92^{\circ} 39^{\prime} 54^{\prime \prime}$ & 2011 & 835.17 & 42.4 \\
\hline 415856092392001 & 083N16W24DBDD 2011MMW-4A & $4 \mathrm{~A}$ & $41^{\circ} 58^{\prime} 56^{\prime \prime}$ & $92^{\circ} 39^{\prime} 20^{\prime \prime}$ & 2011 & 830.41 & 39.5 \\
\hline 415908092401901 & 083N16W23DABA 2011MMW-5A & $5 \mathrm{~A}$ & $41^{\circ} 59^{\prime} 08^{\prime \prime}$ & $92^{\circ} 40^{\prime} 19^{\prime \prime}$ & 2011 & 831.85 & 32.5 \\
\hline 415806092394501 & 083N16W25CACD 2011MMW-6A & ${ }^{1} 6 \mathrm{~A}$ & $41^{\circ} 58^{\prime} 46.2^{\prime \prime}$ & $92^{\circ} 39^{\prime} 46^{\prime \prime}$ & 2011 & 828.28 & 17.0 \\
\hline 415806092394502 & 083N16W25CACD 2019MMW-6B & $6 \mathrm{~B}$ & $41^{\circ} 58^{\prime} 46.2^{\prime \prime}$ & $92^{\circ} 39^{\prime} 46^{\prime \prime}$ & 2019 & 828.28 & 17.0 \\
\hline 415855092394701 & 083N16W24CDBB 2011MMW-7A & $7 \mathrm{~A}$ & $41^{\circ} 58^{\prime} 55^{\prime \prime}$ & $92^{\circ} 39^{\prime} 47^{\prime \prime}$ & 2011 & 826.77 & 38.0 \\
\hline 415855092393501 & 083N16W24CDAA 2011MMW-8A & $8 \mathrm{~A}$ & $41^{\circ} 58^{\prime} 55^{\prime \prime}$ & $92^{\circ} 39^{\prime} 35^{\prime \prime}$ & 2011 & 826.83 & 35.0 \\
\hline 415906092392001 & 083N16W24DBAA 2011MMW-9A & $9 \mathrm{~A}$ & $41^{\circ} 59^{\prime} 06^{\prime \prime}$ & $92^{\circ} 39^{\prime} 20^{\prime \prime}$ & 2011 & 841.50 & 42.5 \\
\hline 415924092393701 & 083N16W24BADD 2011MMW-11A & $11 \mathrm{~A}$ & $41^{\circ} 59^{\prime} 24^{\prime \prime}$ & $92^{\circ} 39^{\prime} 37^{\prime \prime}$ & 2011 & 829.69 & 41.7 \\
\hline 415911092395601 & 083N16W24BCDC 2011MMW-12A & $12 \mathrm{~A}$ & $41^{\circ} 59^{\prime} 11^{\prime \prime}$ & $92^{\circ} 39^{\prime} 56^{\prime \prime}$ & 2011 & 828.25 & 40.0 \\
\hline 05451770 & $\begin{array}{l}\text { Iowa River at County Highway E49 near Tama, } \\
\text { Iowa }\end{array}$ & Iowa River & $41^{\circ} 57^{\prime} 51.32^{\prime \prime}$ & $92^{\circ} 38^{\prime} 11.58^{\prime \prime}$ & 2011 & 810.47 & -- \\
\hline
\end{tabular}

${ }^{1}$ Well found destroyed on December 3, 2019, and replaced with 6B. 
contour line placement: (1) the water table was assumed to be below the land surface and approximate land surface topography; (2) the upland areas underlain by glacial till have a low hydraulic conductivity compared to the high hydraulic conductivity of the alluvial sediments that underlay the river valley, therefore, steep hydraulic gradients were assumed near upland transitions (Hallberg and others, 1978); (3) the Iowa River has perennial flow in the study area, therefore, groundwater gradients in the river valley were assumed to be low with gradients sloping from the upland margin toward the stream channel (from the northwest to the southwest) and following the general gradient of the valley (from the northwest to the southeast), sloping in the downstream direction; and (4) a cone of depression was assumed because of withdrawals, with gradients sloping toward the well field; this assumption was made because multiple observations were not available to interpolate the geometry and slope of the cone of depression. The water table illustrated in figure 2 shows typical drought/ low-flow conditions for the IRAA in the study area. The components and importance of the water-table map are discussed in the "Hydrology" section of this report.

\section{Integrated Qualitative Analysis}

To assess how stage on the Iowa River, local precipitation, and operation of the well field affect observed elevations of the groundwater table, three periods of data were selected for analysis. One period was selected to exemplify the effect of sustained low stage on the Iowa River on watertable elevation (July 1 to September 30, 2020), one period was selected to exemplify the effect of sustained high stage on the Iowa River on water-table elevations (September 1 to November 30, 2018), and one period was selected as an example of variable stage from localized precipitation events versus upstream flows (February 10 to July 10, 2020). Daily groundwater withdrawals and precipitation are variable throughout each of these periods. A reference line of 250,000 gallons per day was applied to the daily groundwater withdrawal data provided by the MNDNR and indicated typical withdrawals from the IRAA. Actual daily groundwater withdrawal volumes were put on a relative scale from 0 to 1 to illustrate deviation from typical with-drawal volume. 


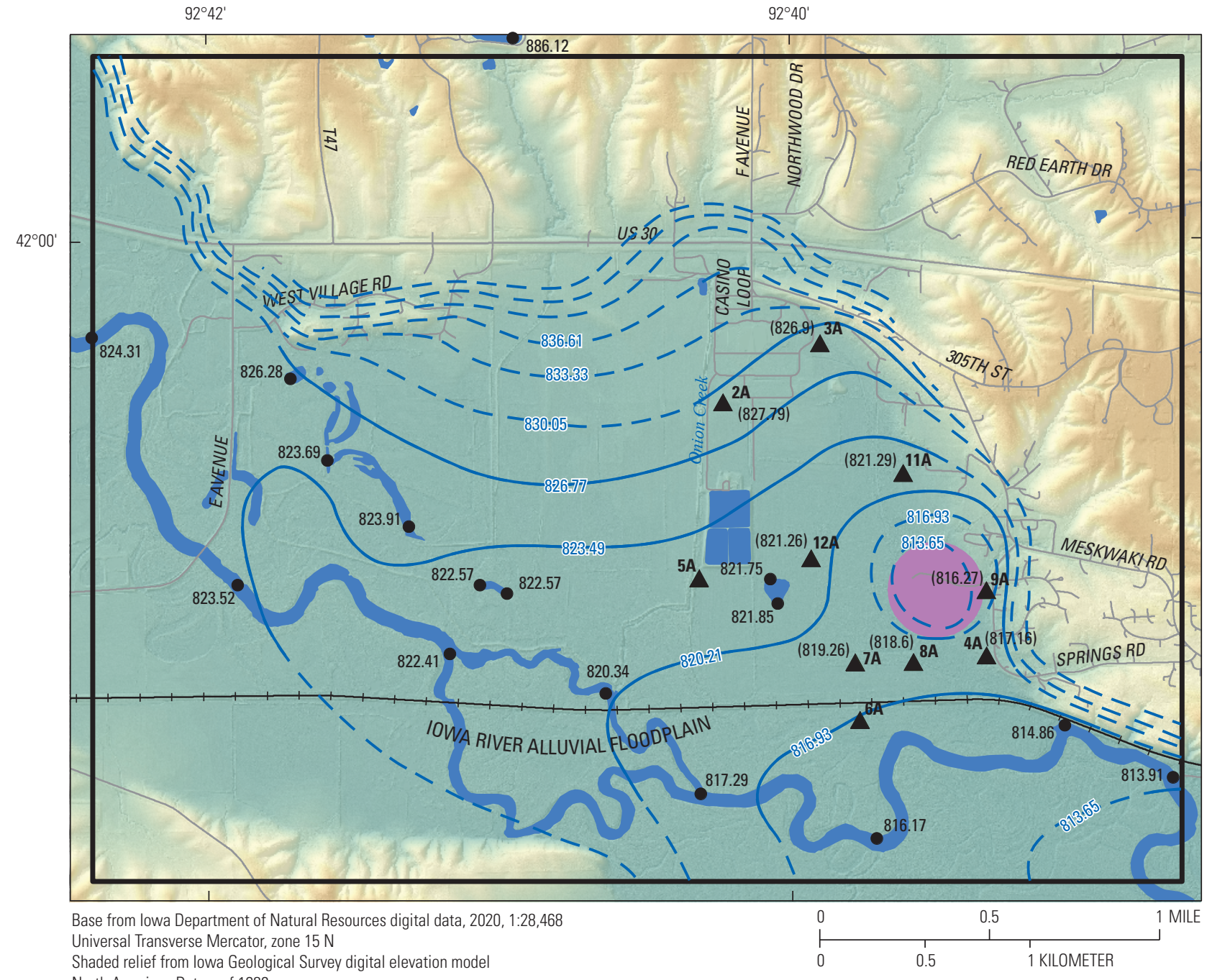

Sed relief from lowa Geological Survey digital elevation model

North American Datum of 1983

EXPLANATION

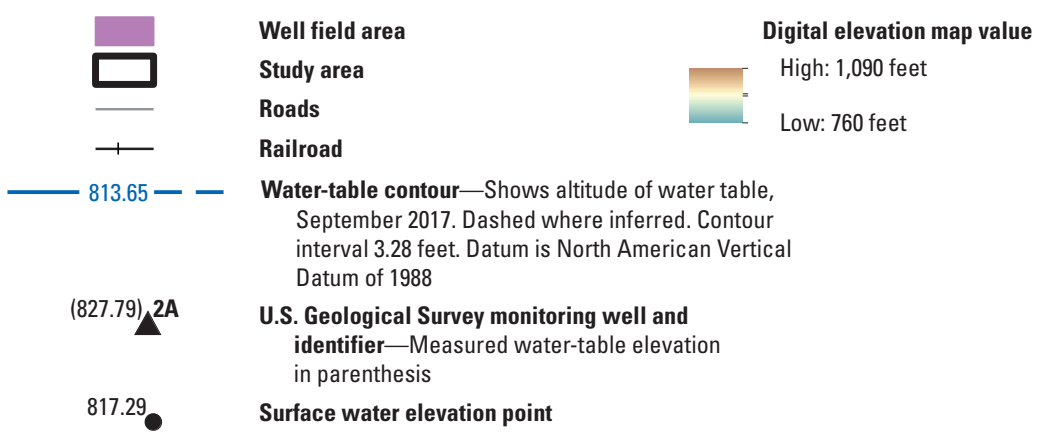

Figure 2. Water-table elevations typical of drought/low flow conditions for the lowa River alluvial aquifer near Tama, lowa, as represented by September 2017 elevations. 


\section{Hydrologic Effect of Groundwater Withdrawals, River Stage, and Precipitation on the lowa River Alluvial Aquifer}

The hydrologic setting of the study area includes groundwater and surface water interaction, topography, surficial geology, well field operations, and climate. The water-table map created for the study area provides a typical surface of the water table for low-flow/drought conditions observed in September 2017. In general, high hydraulic gradients are observed near the upland margin, and low gradients are associated with the valley floor (fig. 2). The water-table map indicates (based on water-table elevations) that within most of the study area, groundwater generally flows toward the stream channel and to the southeast (downstream), with one exception; near the well field, groundwater withdrawals were assumed to have created a cone of depression and water levels are assumed to be lower than the surrounding area (fig. 2).

To better characterize the water-table changes compared to stage on the Iowa River, groundwater withdrawals, daily mean groundwater elevation data, and local precipitation were analyzed. Three periods of data were used to illustrate and assess changes to the water table related to sustained low stage, sustained high stage, and variable stage. For each period, all the available groundwater data for that period were used and the associated figures were generally organized so the wells with the highest water-table elevations were at the top and descended to the Iowa River stage, which is at the bottom. This is consistent with the presumed typical direction of groundwater flow and the water-table elevation map (fig. 2). Water levels in well 9A are considered indicative of water levels in the cone of depression caused by the pump-ing wells in the well field.

\section{Effect of Sustained Low Stage on Water-Table Elevations}

To examine the effect of sustained low stage on watertable elevations, a period of hydrologic data from July 1 to September 30, 2020, was analyzed to determine how low stage on the Iowa River, groundwater withdrawals, and precipitation affect water-table elevations (fig. 3). During this period water-table elevations are gradually declining and it is a period of little precipitation with only a couple of substantial rainfall events, most notably 0.88 inch (in.) on August 11 and a combined 5.33 in. from September 8 to 12 (National Oceanic and Atmospheric Administration, 2020).

The water table during this period is consistent with the water-table elevation map and indicates groundwater flows in the south to southeasterly direction with a cone of depression around the well field (figs. 2, 3). Based on observations in groundwater withdrawal data, it is apparent that the volume of groundwater being withdrawn has more of an acute effect during periods of drought. Changes in withdrawals during

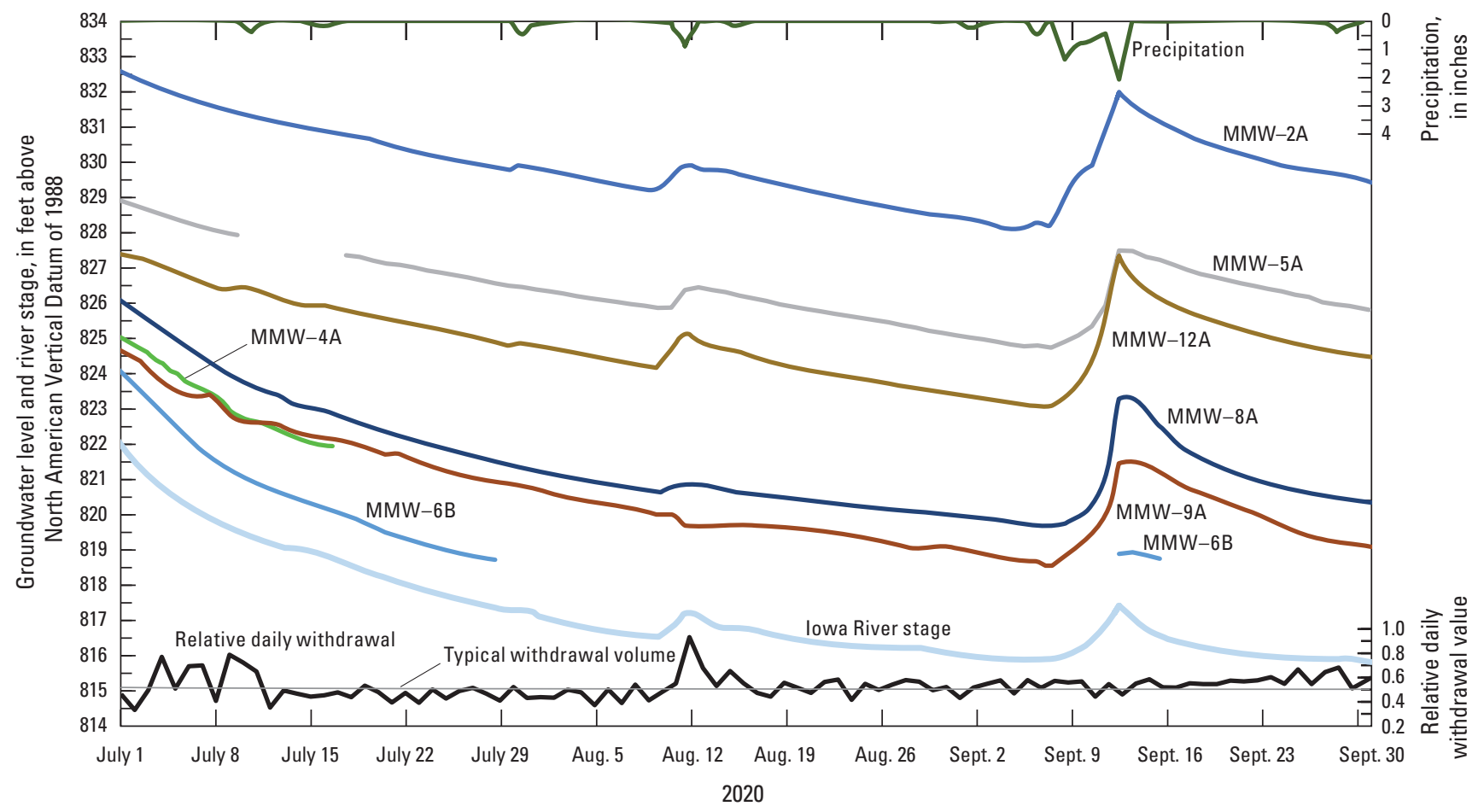

Figure 3. Daily mean water-table elevations, relative groundwater withdrawals, and precipitation, July 1 to September $30,2020$. 
low-stage conditions are observed to affect groundwater levels, whereas during higher stages, this is not typically observed. In general, and especially the first 2 weeks of July 2020, when pumping was more variable, small increases and decreases in the water table were observed in the cone of depression (9A) and were inverse to groundwater withdrawals; when withdrawals are reduced, the water table rises, and when withdrawal is increased, the water table falls (fig. 3). On August 11, 2020, there was 0.88 in. of precipitation (National Oceanic and Atmospheric Administration, 2020) that caused water levels to increase at all of the actively monitored locations in the study area at that time; well 9A was the exception, and increased withdrawal caused a decrease in water levels. After the 5.33 in. of rainfall on September 8-12, 2020, a 2- to 3 - $\mathrm{ft}$ increase in water level elevations was observed at all the monitoring wells and on the Iowa River (fig. 3).

\section{Effect of Sustained High Stage on Water-Table Elevations}

To better characterize how higher stage affects watertable elevations in the well field, a period from September 1 to November 30, 2018, was analyzed to determine how high stage on the Iowa River, groundwater withdrawals, and precipitation affect water-table elevations (fig. 4). Groundwater withdrawals during this period were generally consistent, with a couple larger withdrawals occurring in late October and mid-November. During the summer of 2018, before this analysis period, stage on the Iowa River was typical of normal streamflow. September 2018 was a wet month, and 13 in. of precipitation was recorded at the nearby NOAA climate station (National Oceanic and Atmospheric Administration, 2020). Five large (greater than 1 in.) precipitation events occurred during this month. From September 1 to $6,8.53$ in. of precipitation was recorded. From September 19 to 21, 1.98 in. of precipitation fell, and on September 26, 2.18 in. of precipitation fell (National Oceanic and Atmospheric Administration, 2020). Additionally, on October 1-10, there was a rainfall event every day, and a combined 4.76 in. of precipitation was recorded over these 10 days (National Oceanic and Atmospheric Administration, 2020). These rainfall events led to one large peak in stage that occurred from about September 2 to 12, followed by an equally large but longer peak that occurred during sustained high flows from September 21 to October 19, 2018 (fig. 4).

Generally, convergence is observed in the water level elevations among the monitoring wells when there is abundant local precipitation and stage on the Iowa River is high. During the first peak, well 8A seemed to have been overtopped, which may have damaged the integrated pressure sensor; it stopped working after the recession and before the next more sustained event(s) (fig. 4). Because of the high water prohibiting access to well 8A, a transducer was deployed in well 4A to continue collecting groundwater data while these high-stage events were occurring.

During peak water level, river stage was slightly higher than the observed water-table elevations in well 9A, which is the closest monitoring well to the well field and was used throughout this study as a general indicator of extent of the

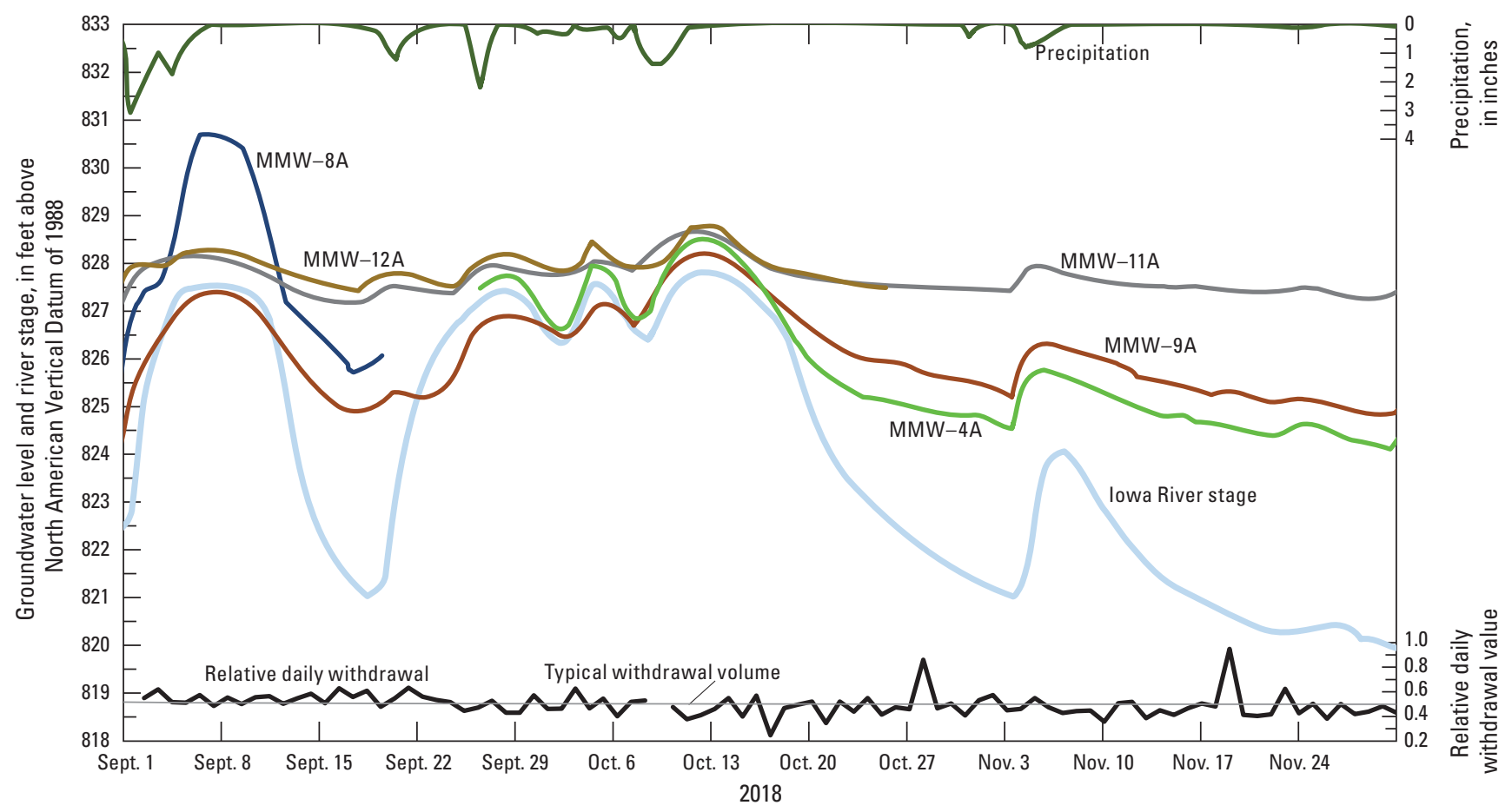

Figure 4. Daily mean water-table elevations, relative groundwater withdrawals, and precipitation, September 1 to November 20 , 2018. 
cone of depression (fig. 4). Well 4A had higher water-table elevation values when compared to well 9A for a similar period. Once the river started to recede, water-table elevations for well 4A dropped below those of well 9A. Wells 11A and $12 \mathrm{~A}$ generally had water levels that trended similarly to one another and were higher than water levels in wells $4 \mathrm{~A}$ and 9A. This indicates that during these periods of high stage and abundant local precipitation, water is flowing into the IRAA from the uplands and from the Iowa River (fig. 4). After high stage on the Iowa River, water-table elevations diverged again as the river receded in mid-October. With the recharge to the IRAA from the Iowa River and local rainfall, the increased groundwater withdrawals in late October and mid-November 2018 were not observed to cause much of an effect on groundwater elevations anywhere in the study area. A groundwater flow model could better quantify the volumes of water moving into the IRAA during these types of events.

\section{Variable Stage from Localized Precipitation Events Versus Upstream Flow Events}

To gain insight into how a period of variable stage on the Iowa River affects groundwater elevations in the IRAA, a 5-month period of data from February 10 to July 10, 2020, was analyzed to determine how variable stage on the Iowa River, groundwater withdrawals, and precipitation affect water-table elevations (fig. 5). During this period, a large range (about $10 \mathrm{ft}$ ) of stage was observed with some high-stage events being caused more by upstream flows, whereas other events were caused more by a combination of upstream flows and local precipitation. Depending on the cause of the high stage, the observed responses in the IRAA are slightly different.

In mid-March 2020, there was a multiday rainfall event when 1.24 in. of precipitation was recorded from March 18 to 20 (National Oceanic and Atmospheric Administration, 2020), but much of the increase in stage that was observed was caused by upstream flows coming downstream rather than local runoff. The slope of the water table did not change much; however, at the peak of this rainfall event, well 6B and the Iowa River were higher than well 9A, which may indicate that the elevated railroad track may act as an obstruction at times when high stage is the result of upstream flows (fig. 5). Similarly, another high-stage event on May 30 seems to be a combination of upstream flows and local precipitation. The response was similar to the mid-March event, but with the slower rate of rainfall (2.12 in. from May 23 to 29), it is presumed there was increased local infiltration and runoff. As a result, the wells nearest the river $(6 \mathrm{~B})$, the railroad tracks (7A, 8A, and 4A), and Onion Creek (5A) indicated a response to this event whereas wells $2 \mathrm{~A}$ and $12 \mathrm{~A}$ indicated little to no response. Wells $12 \mathrm{~A}$ and $2 \mathrm{~A}$ are farther north and farther away from surface water bodies and the railroad tracks. The railroad tracks might have the dual effect of impounding water

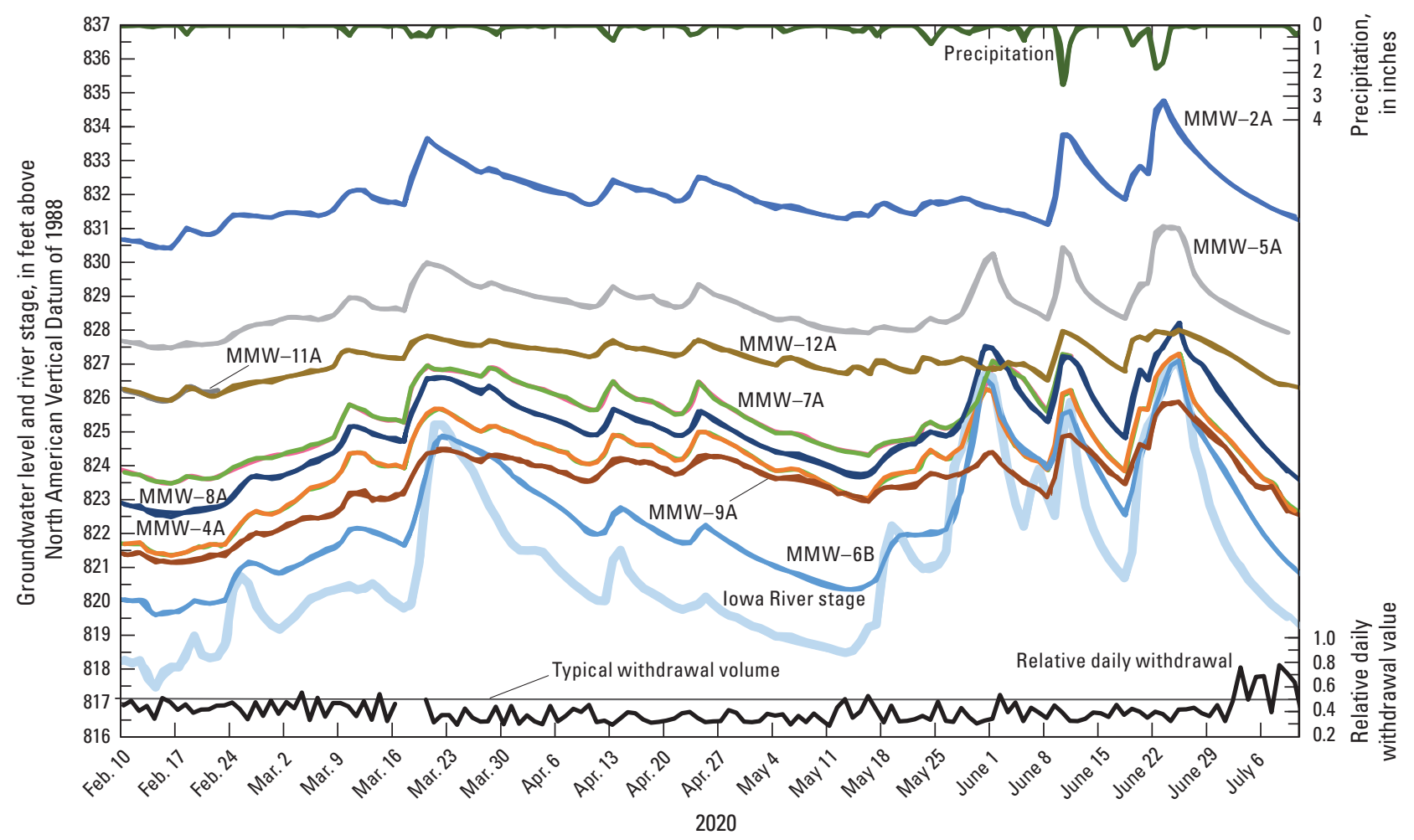

Figure 5. Daily mean water-table elevations, relative groundwater withdrawals, and precipitation, February 10 to July 10 , 2020. 
and increasing the residency time of the surface water, which may lead to increased recharge near the well field during local precipitation-induced high stage while prohibiting water from entering the well field when high stage is more affected by upstream flows.

Two additional peak high stages were observed in June 2020 but were much more affected by local precipitation and drainage (fig. 5). On June 10-11, 3.25 in. of precipitation was recorded at the NOAA climate station (Toledo $3 \mathrm{~N}$, IA US), and from June 22 to 23, after 3 days of moderate to light rainfall, 3.39 in. of precipitation was recorded (National Oceanic and Atmospheric Administration, 2020). Responses to these events are observed in the recorded data in all the monitoring wells. The Iowa River and well 6B have water levels that indicate groundwater gradients sloping toward the well field when they typically slope toward the Iowa River. Qualitative groundwater modeling coupled with the floodinundation model developed by Cigrand (2019a) could help to better quantify and demonstrate how water is moving in the floodplain with respect to well field operations and stage on the Iowa River.

\section{Summary and Conclusions}

The Sac and Fox Tribe of the Mississippi in Iowa is the only federally recognized Tribe in the State of Iowa and is commonly known as the Meskwaki Nation. The Tribe owns more than 8,100 acres, referred to as the "Meskwaki Settlement." The Meskwaki Settlement uses a well field that withdraws water from the Iowa River alluvial aquifer (IRAA) to supply drinking water to members of the Tribe. Increased severity and timing of flooding and drought conditions, coupled with water-quality concerns in the Iowa River, have prompted the Meskwaki Nation to start identifying tools to provide a better understanding of how extreme climate events (changes in streamflow, flood frequency, and magnitude and persistence of drought conditions), increasing water-supply demands, and groundwater storage depletion will affect water availability in the IRAA.

From June 2017 through September 2020, the U.S. Geological Survey in cooperation with the Meskwaki Nation, collected continuous and discrete groundwater level data from 11 wells in a U.S. Geological Survey monitoringwell network. Groundwater level data collected at these wells were assessed with daily precipitation data and compared to changes in stream level (stage) elevations and daily groundwater withdrawals to determine how these changes affect groundwater-table elevations. Results from this study could be used to guide the development of a conceptual model for groundwater flow and a groundwater flow model for the IRAA to be used to quantify and forecast the effect of Iowa River streamflow, groundwater withdrawals, and local precipitation on the water table in the IRAA.
Three periods of data were used to demonstrate how the water table changes in relation to stage on the Iowa River, well field operations, and local precipitation. A low-stage period from July 1 to September 30, 2020, indicated that the water table is generally flowing in the downstream direction and the effects of well field operations on the water table are more apparent. Inputs from precipitation during dry periods indicate infiltration to the IRAA. A high-stage period from September 1 to November 30, 2018, indicated that during periods of high stage and abundant local precipitation, water is flowing into the well field area from the uplands and from the Iowa River. During high stage on the Iowa River, water-table elevations are all similar across the floodplain, but as the river recedes, the water-table elevations begin to diverge again. Well field operations in late October and mid-November 2018 were not observed to cause much of an effect on groundwater elevations within the IRAA. A period with variable stage from February 10 to July 10, 2020, indicated that the water table can respond differently depending on whether high stage on the Iowa River is the result of upstream flows or localized precipitation events. The railroad can impound water and promote recharge to the well field during local precipitation events, whereas during upstream flow events, it can restrict water from entering the well field. Qualitative groundwater modeling coupled with the flood-inundation model could help to better quantify and demonstrate how water is moving in the floodplain with respect to well field operations and stage on the Iowa River.

\section{References Cited}

Cigrand, C.V., 2019a, Flood-inundation maps for the Iowa River at the Meskwaki Settlement in Iowa, 2019: U.S. Geological Survey Scientific Investigations Report 2019-5050, 12 p., accessed November 2020 at https://doi.org/10.3133/sir20195050.

Cigrand, C.V., 2019b, Geospatial datasets for the floodinundation study for the Iowa River at the Meskwaki Settlement in Iowa, 2019: U.S. Geological Survey data release, accessed November 2020 at https:/doi.org/10.5066/ P912FO3L.

Cunningham, W.L., and Schalk, C.W., comps., 2011, Groundwater technical procedures of the U.S. Geological Survey: U.S. Geological Survey Techniques and Methods, book 1, chap. A1, 151 p., accessed March 3, 2021, at https://doi.org/10.3133/tm1A1. 
Hallberg, G.R., Fenton, T.E., Miller, G.A., and Luteneggar, A.J., 1978, The Iowan erosional surface - An old story, an important lesson, and some new wrinkles, in Anderson,

R.R., ed., 42nd Annual Tri-State Geological Field

Conference on Geology of East-Central Iowa Guidebook, October 13-15, 1978: Cedar Rapids, Iowa, 224 p., 91 figs., 4 tables, 1 pl., 1 appendix.

Iowa Department of Natural Resources, 2017, Three meter digital elevation model of Linn County, Iowa, derived from LiDAR: Iowa Geodata digital data, accessed October 1, 2019, at https://geodata.iowa.gov/datasets/iowadnr:threemeter-digital-elevation-model-of-iowa.

Iowa Geological Survey, 2020, GeoSam lithologic database: Iowa Geological Survey web page, accessed November 16, 2020, at https://www.iihr.uiowa.edu/igs/geosam/home.

Littin, G.R., and McVay, J.C., 2008, Water-quality and biological assessment of the Iowa River and tributaries within and contiguous to the Meskwaki Settlement of the Sac and Fox Tribe of the Mississippi in Iowa, 2006-07: U.S. Geological Survey Scientific Investigations Report 2009-5105, 41 p. [Also available at https://doi.org/10.3133/sir20095105.]
National Oceanic and Atmospheric Administration, 2020, Daily summaries station details: National Oceanic and Atmospheric Administration, National Centers for Environmental Information web page, accessed November 10, 2020, at https: //www.ncdc.noaa.gov/cdo-web/datasets/GHCND/stations/ GHCND:USC00138296/detail.

Rantz, S.E., and others, 1982, Measurement and computation of streamflow-Volume 1. Measurement of stage and discharge: U.S. Geological Survey Water-Supply Paper 2175, 284 p., accessed March 3, 2021, at https://doi.org/10.3133/ wsp2175.

U.S. Geological Survey, 2020, USGS water data for the Nation: U.S. Geological Survey National Water Information System database, accessed November 6, 2020, at https://doi.org/10.5066/F7P55KJN. 

For more information about this publication, contact: Director, USGS Central Midwest Water Science Center 400 South Clinton Street, Suite 269

lowa City, IA 52240

319-337-4191

For additional information, visit: https://www.usgs.gov/ centers/cm-water

Publishing support provided by the

Rolla Publishing Service Center 


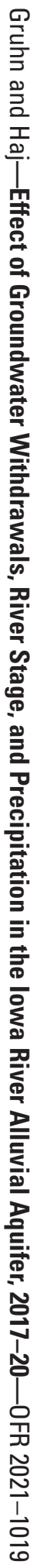

